\title{
Specific Associations Between Clinical Signs, Immune Cells, Disease Genetic Background and Burden in a Group of Patients with B-Cell Chronic Lymphocytic Leukemia
}

\author{
Asocieri specifice între simptomatologia clinică, celulele non-maligne, \\ defectele genetice și încărcătura tumorală la pacienți cu \\ leucemie limfocitară cronică B
}

\author{
Georgiana Emilia Grigore ${ }^{1.2^{*}}$, Iuliu C. Ivanov ${ }^{1.2}$, Mihaela Zlei ${ }^{2}$, Angela \\ Dăscălescu ${ }^{1}$, Roxana Popescu ${ }^{1}$, Tudor Petreuș ${ }^{1.2}$, Eugen Carasevici ${ }^{2}$
}

1. University of Medicine and Pharmacy Grigore T. Popa of Iasi, Romania

2. Regional Institute of Oncology, Iasi, Laboratory of Molecular Biology

\begin{abstract}
Traffic of tumor-and normal cells through the peripheral blood (PB) of patients with B-cell chronic lymphocytic leukemia (B-CLL) to the lymph nodes (LN) or spleen/liver sites is governed by specific changes in surface and intracellular molecule expression. The study aims to investigate the potential association between different lymphocyte subsets, chemokine receptors or genetic alterations and specific clinical signs in a group of B-CLL patients. Forty-three patients were included in the study. The expression of CCR7, CXCR5, CXCR3, CCR4, CD3, CD4, CD8, CD27, CD28, CD45RA, CD25, CD127, CD38 was tested by multiparameter flow cytometry. Genetic alterations were determined by MLPA. We found increased frequency of CD38+B-CLL cells directly correlated with the presence of $L N>5 \mathrm{~cm}$. CXCR5 and CCR7 are homogenously expressed by monoclonal B-CLL cells. CCR4+ $B-C L L$ cell frequency is found to be lower in the PB of patients presenting particular LN involvement. Heterogeneous and complex genetic alterations were found and only the presence of trisomy 12 associated with less frequent axillary $L N$ involvement. We also report a significant increase in the frequency of total $T$ cells and $T$ cell subsets (effector-and central memory CD4+ T cells, regulatory $T$ cells, follicular T helper cells, distinct functional CD8 $+T$ cells) with the occurrence of specific clinical manifestations. Chemokine receptor expression on circulating CD4+ $T$ cell subsets was augmented in connection to some specific LN locations. Consequently, clinical manifestations in B-CLL are linked to both, factors intrinsic to the monoclonal B cells, and external influences coming from the microenvironment.
\end{abstract}

Keywords: B-CLL, genetic lesions, microenvironment.

*Corresponding author: Georgiana Emilia Grigore, Regional Institute of Oncology, Iasi, Laboratory of Molecular Biology, phone: +40 740842927, e-mail: georgiana_grig@yahoo.com 


\section{Rezumat}

Traficul limfocitelor maligne și normale prin sângele periferic (PB) către ganglioni, splina și ficat este guvernat de modificări specifice ale nivelelor de expresie de suprafață/ intracelulară a unor molecule. Studiul ișsi propune să investigheze asocierea dintre diferite subseturi limfocitare, receptori pentru chemokine sau aberații genetice și anumite simptome clinice la pacienți cu LLC-B. Patruzeci și trei de pacienți au fost incluși în studiu. Prin citometrie în flux multiparametrică a fost testată expresia pentru CCR7, CXCR5, CXCR3, CCR4, CD3, CD4, CD8, CD27, CD28, CD45RA, CD25, CD127, CD38. Defectele genetice au fost determinate prin MLPA. Am observat o frecvență crescută a celulelor CD38+ clonale corelată cu infiltrarea ganglionilor $>5 \mathrm{~cm}$. CXCR 5 si CCR7 sunt omogen exprimați de celulele de LLC-B. Frecvența celulelor B CCR4+ este redusă la pacienții cu un anumit tip de infiltrare ganglionară. Am detectat aberații genetice heterogene și complexe și trisomia 12 este mai frecventă la pacienții ce nu prezintă ganglioni axilari. Deasemenea, frecvența limfocitelor T totale și a unor subseturi (memorie efector și centrală, T reglatorii, T helper foliculare, diferite subseturi funcționale CD8+) este crescută doar concomitent cu prezența anumitor manifestări clinice. Expresia receptorilor pentru chemokine la nivelul limfocitelor $T$ $C D 4+$ este crescută în conexiune cu anumite localizări ganglionare. In concluzie, manifestările clinice la pacienții cu LLC-B sunt în strânsă legatură atât cu factori intrinseci limfocitelor B clonale, cât și de influențe externe, furnizate de semnale provenite din micromediu.

Cuvinte cheie: $L L C-B$, leziuni genetice, micromediu

Received: $1^{\text {st }}$ October 2013; Accepted: $8^{\text {th }}$ February 2014; Published: $28^{\text {th }}$ February 2014.

\section{Introduction}

Chronic lymphocytic leukemia (B-CLL) is a complex immune disease, characterized by high circulating numbers of monoclonal B cells. The expansion of these B-cells is associated with severe defects of T-cell responses and homeostasis. Accordingly, we and others have documented proofs of a systemic immune dysregulation in CLL patients, including increased circulating $\mathrm{T}$ cell numbers with disease stage, imbalanced Th1/Th2 profiles, increased circulating numbers of regulatory phenotypes, and reduced B-cell capacity for antigen presentation, among others, which may lead to immunodeficiency or autoimmune manifestations related to the disease $[1,2]$. Additionally, hepato- and splenomegaly and the occurrence of enlarged lymph nodes (LN) with various localizations are considered the most frequent clinical manifestations in B-CLL patients [3]. Trafficking of B-CLL cells between different compartments, through peripheral blood (PB), is governed by changes in surface and intracellular molecules and by micro-environmental signals and interactions [4-6]. Such interactions contribute to the regulation of proliferation/ apoptosis events within the malignant clone and provide conditions for the acquisition of genomic alterations $[7,8]$.

The study of phenotypic changes and specific microenvironmental interactions in B-CLL, currently partially understood, may provide relevant information for the behavior of malignant B-cells and may contribute to the design of novel therapeutic strategies, as current therapies do not effectively reach the residual disease pool in secondary lymphoid organs and bone marrow [6].

Our study aims to investigate whether there is a preferential migration of distinct lymphocyte populations from B-CLL patients towards spleen, liver, or different LN sites. Also the study intended to find specific linkage between the tissue involvement and factors intrinsic to the disease: genetic aberrations, chemokine receptor expression by the tumor clone, and circulating $\mathrm{T}$ cell subsets considered representative components of the tumor microenvironment in B-CLL. 


\section{Material and methods}

\section{Patients and samples}

The group of subjects included in the present study consisted of 43 patients $(27$ males and 16 females) hospitalized and diagnosed with B-CLL in the Hematology Clinic, St Spiridon Hospital/ Regional Institute of Oncology, Iasi, Romania. Six to nine $\mathrm{mL}$ of $\mathrm{PB}$ were harvested on EDTA after informed consent was obtained from each individual, in accordance to the Local Ethical Committee. Clinical data were recorded: the presence of organomegaly (spleen and liver) and LN involvement (all LN chains larger than $2 \mathrm{~cm}$ were taken into account, and cervical, supraclavicular, axillary and inguinal localization).

\section{Flow cytometry studies}

Circulating B-CLL cells were identified and quantified by multicolour flow cytometry in fresh PB samples using the standard stain-lyse and wash procedure. The monoclonal antibody combination used included: CD19, CD20, CD22, CD5, CD23, CD10, CD38, kappa, lambda, IgM, IgD, IgG. A total number of $1 \times 10^{5}$ events per tube was acquired and analysed. For the analysis of $\mathrm{T}$ cell subsets and chemokine expression on B-CLL and T-cells, peripheral blood mononuclear cells (PBMCs) were separated by density gradient centrifugation with Histopaque (Sigma) and stored at $-150^{\circ} \mathrm{C}$ in freezing medium (RPMI/ FCS/ DMSO) until use. The cells were then thawed, washed twice in PBS and stained with anti-CCR7, CXCR5, CXCR3, CCR4, CD3, CD4, CD8, CD27, CD28, CD45RA, CD25, CD127 (BD Biosciences - San Jose, CA). Data acquisition $\left(2 \times 10^{6}\right.$ events per tube $)$ was carried out using a BD FACS Aria III cytometer and data analysis performed using the Infinicyt software (Cytognos, Salamanca, Spain).

\section{Cell subsets identification}

Monoclonal B cells were identified by their particular phenotype: CD19+ CD20+low CD5+ $\mathrm{CD} 23+$ and light chain restriction (either kappa or lambda). CD4+ CD8- T lymphocytes were grouped according to their phenotypic differentiation (Table $I$ ) in naive $(\mathrm{N})$, central memory (CM), effector memory (EM), follicular (TFH), and regulatory (Tregs) CD4+ T cells. Further Th1 and Th2 associated profiles were identified according to their expression of CXCR3 or CCR4, respectively. Four subsets were identified within CD4- CD8+ T cell population, according to CD27 and CD28 expression (Table I): Tc1 (containing the naive and memory cytotoxic pool), and three effector types of cytotoxic $\mathrm{T}$ cells: Tc2, Tc3, Tc4.

Table I. Phenotype of circulating T cell subsets in B-CLL patients

\begin{tabular}{|c|c|c|c|c|c|c|c|c|}
\hline & & CCR7 & CD45RA & CD27 & CD28 & CXCR5 & CD25 & CD127 \\
\hline \multirow{5}{*}{$\begin{array}{l}\text { CD4 T cell } \\
\text { subsets }\end{array}$} & naive & + & + & \multicolumn{5}{|c|}{ na } \\
\hline & $\mathrm{CM}$ & + & - & \multicolumn{5}{|c|}{ na } \\
\hline & EM & - & - & \multicolumn{5}{|c|}{ na } \\
\hline & TFH & + & - & \multicolumn{2}{|c|}{ na } & + & \multicolumn{2}{|c|}{ na } \\
\hline & T reg & \multicolumn{2}{|c|}{ na } & $+/-$ & $+/-$ & na & +++ & $-/+$ \\
\hline \multirow{4}{*}{$\begin{array}{l}\text { CD8 T cell } \\
\text { subsets }\end{array}$} & TC1 & \multicolumn{2}{|c|}{ na } & + & + & \multicolumn{3}{|c|}{ na } \\
\hline & TC2 & \multicolumn{2}{|c|}{ na } & - & + & \multicolumn{3}{|c|}{ na } \\
\hline & TC3 & \multicolumn{2}{|c|}{ na } & + & - & \multicolumn{3}{|c|}{ na } \\
\hline & TC4 & \multicolumn{2}{|c|}{ na } & - & - & \multicolumn{3}{|c|}{ na } \\
\hline
\end{tabular}

na-not assessed; CM-central memory; EM-effector memory; TFH-follicular helper T cells, TC-cytotoxic T cell, $\mathrm{T}$ reg - regulatory $\mathrm{T}$ cells 


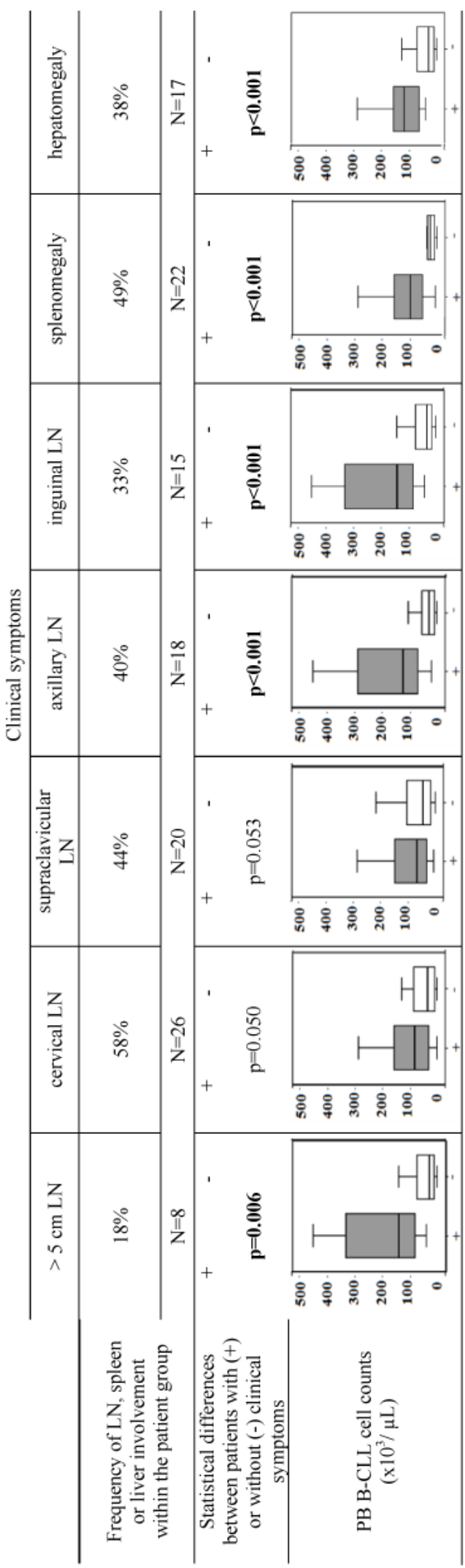

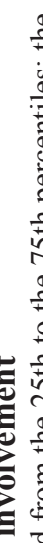

$\stackrel{\Xi}{ \pm}$ oิ 릉 离 点电 로음 봏 政

\section{Molecular biology analysis}

For the MLPA analysis (Multiplex Ligation-Dependent Probe Amplification) two commercial kits were used (SALSA MLPA P037 and P038 CLL, MRC Holland). DNA was extracted from PBMCs $\left(5 \times 10^{6}\right.$ cells $)$ using a Promega kit-Wizard Genomic DNA Purification kit, then diluted to a final concentration of $40 \mathrm{ng} / \mu \mathrm{L}$. Five $\mu \mathrm{L}$ of DNA were used for each reaction following the standard protocol indicated by MRC Holland and previously described in detail [9]. In each of the runs at least one normal (non B-CLL) DNA specimen was tested. The hybridization, ligation and PCR amplification were performed on a SensoQuest Lab cycler (Biomedical Electronics), and the capillary electrophoresis on CEQ 8000 (Beckman Coulter) with GenomeLab DNA size standard 600 (Beckman Coulter). Data interpretation was performed using Coffalyser. Net MLPA data analysis software, 2013 version.

\section{Statistical Methods}

Mean values, and standard deviation, median and range values were calculated for all continuous variables, and relative frequencies were determined for categorical variables using the SPSS statistical software (SPSS 21 Inc., Chicago, IL). Statistical significance of the differences observed between patients was tested by the Mann-Whitney $U$ and the chi-square tests for non-paired continuous variables and for categorical variables, respectively.

\section{Results}

Association of B-CLL cell accumulation with LN involvement and organomegaly

The assessment of LN, spleen, and liver enlargement within the B-CLL patient group investigated revealed a clinically heterogeneous image (Figure 1). The presence of enlarged spleen, liver, and LN (for axillary, inguinal, and larger than $5 \mathrm{~cm} \mathrm{LN}$, but not for cervical or supraclavicular locations), was found to be associated with significantly higher numbers of circulating B-CLL cells (Table I). Thus, in contrast to patients with no such symptoms, the following 
absolute counts of circulating B-CLL (cells/ $\mu \mathrm{L}$ ) were found significantly increased in patients having splenomegaly or axillary, inguinal, cervical, supraclavicular, and larger than $5 \mathrm{~cm}$ adenopathies (Table I).

\section{Chemokine receptors expression on malignant cells in B-CLL patients grouped based on LN involvement and organomegaly}

In terms of chemokine receptors, malignant clones from B-CLL patients investigated were characterized by a heterogeneous expression pattern for CXCR3 (1-100\% positivity) and CCR4 (13-87\% positivity) (Figure 2), while CXCR5 and CCR7 were homogeneously present within the entire B-CLL group. When the proportion of positivity for each receptor was comparatively assessed based on the presence of LN, spleen, and liver involvement, CCR4 was expressed on a significantly lower proportion of B-CLL cells in patients with supraclavicular $(48 \% \pm 19 \%$ vs $62 \% \pm 14 \%, \mathrm{p}=0.01)$ and inguinal $(46 \% \pm 16 \%$ vs $60 \% \pm 16 \%, \mathrm{p}=0.01) \mathrm{LN}$ involvement, regardless the LN size. No significant difference was found in terms of CXCR3 expression.

Expression of CD38 on malignant B cells was found to be significantly increased in pa- tients having $\mathrm{LN}$ larger than $5 \mathrm{~cm}(39 \% \pm 27 \%$ vs $12 \% \pm 23 \%, p=0.03$ ), with no significant differences linked to the LN localizations. None of the above phenotypic characteristics of B-CLL cells were significantly associated with organomegaly.

\section{Genotypic alterations of B-CLL cells in patients grouped based on $L N$ involvement and organomegaly}

When genotypic alterations within PBMCs of B-CLL patients were assessed by MLPA, copy number alterations were found in 28 of 43 B-CLL cases $(65 \%)$, including 17 cases with simple (40\%) and 11 cases with complex (25\%) abnormalities (Table II). The most frequent alterations were represented by deletion of $13 q 14-\operatorname{del}(13 q)$ (17 cases-40\%), followed by $\operatorname{del}(11 \mathrm{q})(7$ cases-16\%) and trisomy12 $(+12)(6$ cases-14\%). The presence of the genetic lesions was not significantly associated with either adenopathies or organomegaly in our group, except the lower frequency of axillary LN involvement in patients with $+12(p=0.03)$ (Figure 3). No association was found between the chemokine receptors (or CD38) expression on $\mathrm{B}-\mathrm{CLL}$ cells in patients with $\operatorname{del}(11 \mathrm{q}),+12$, or $\operatorname{del}(17 \mathrm{p})$ (Figure 4).

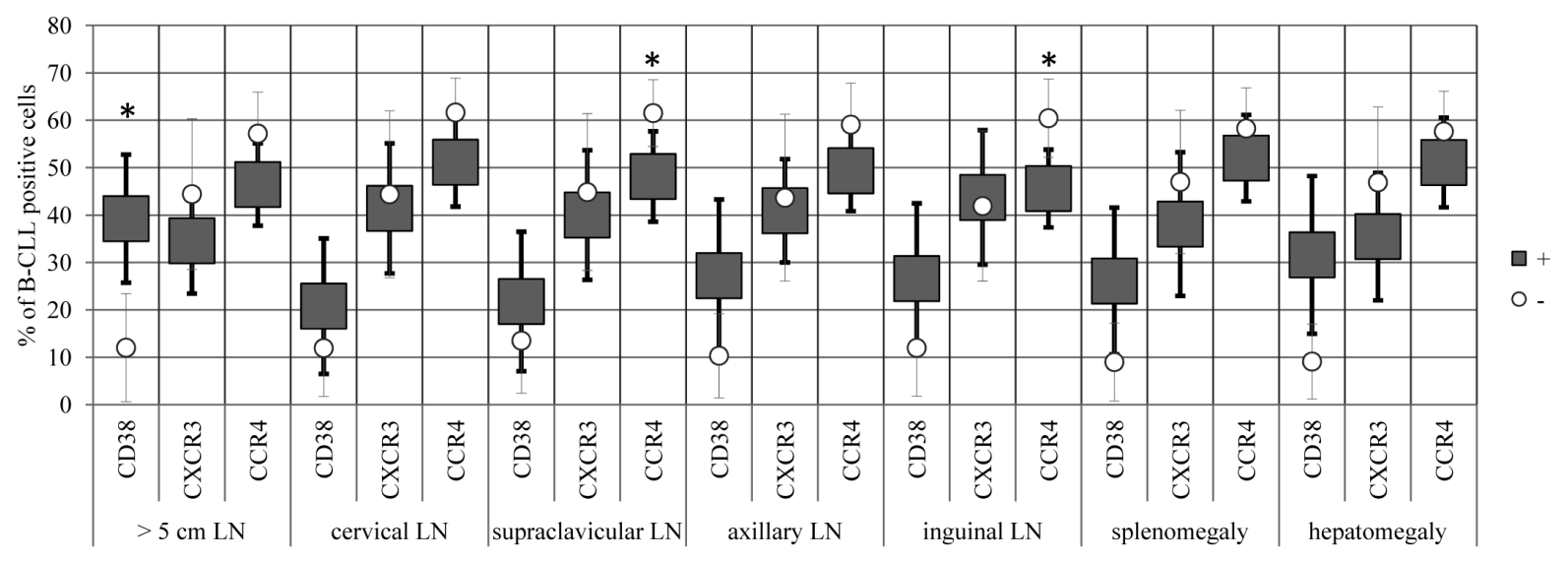

Figure 2. Chemokine receptor (CXCR3 and CCR4) and CD38 expression by monoclonal $B$ cells in B-CLL patients with different clinical manifestations

Frequency of CXCR3+, CCR4+ and CD38+ B-CLL cells in the PB of patients with or without LN/organomegaly involvement. Mean values \pm standard deviation calculated for proportion of positivity in patients with (dark squares) or without (blank circles) clinical signs. *p $<0.05$ for the comparison between presence or absence of symptoms. PB-peripheral blood; LN-lymph node 


\section{Association of PB T cells and adenopa-} thies/organomegaly in B-CLL patients

The presence of adenopathies was found to be linked to higher numbers of circulating total $\mathrm{T}$ cells (cells/ $\mu \mathrm{L}$ ) in B-CLL patients having enlarged cervical $(p=0.004)$, axillary $(p<0.001)$, inguinal ( $\mathrm{p}=0.003)$, and $>5 \mathrm{~cm} \mathrm{LN}(\mathrm{p}=0.04)$ (Figure 5). Total $\mathrm{T}$ cell counts were also increased $(p=0.05)$ in patients presenting enlarged supraclavicular LN (Supplementary data available in the online issue). Some LN locations were associated with significantly higher numbers of total CD4+ T-cells (cells/ $\mu \mathrm{L}$ ), including: cervical $(p=0.004)$, axillary $(p=0.004)$ and inguinal $(p=0.02)$ sites. Patients with adenopathies also presented higher numbers of total PB CD8+ T

Table II. Genetic alterations identified by MLPA analysis and their frequency in B-CLL patients

\begin{tabular}{|c|c|c|c|c|}
\hline & & & $\mathrm{N}$ & $\%$ \\
\hline \multirow{4}{*}{$\begin{array}{l}\text { Simple copy number } \\
\text { alterations } \\
(\mathrm{N}=17)\end{array}$} & $\operatorname{del}(13 q)$ & & 8 & 19 \\
\hline & +12 & & 5 & 12 \\
\hline & $\operatorname{del}(11 q)$ & & 3 & 7 \\
\hline & $\operatorname{del}(17 \mathrm{p})$ & & 1 & 2 \\
\hline \multirow{9}{*}{$\begin{array}{l}\text { Complex alterations } \\
(\mathrm{N}=11)\end{array}$} & $\operatorname{del}(13 q)$ and & $\operatorname{del}(11 q)$ & 2 & 5 \\
\hline & & $\operatorname{del}(17 p)$ & 1 & 2 \\
\hline & & $+8 \mathrm{q}$ and mutated NOTCH1 & 1 & 2 \\
\hline & & $+2 \mathrm{p}$ & 1 & 2 \\
\hline & & +12 & 1 & 2 \\
\hline & & mutated NOTCH1 & 2 & 5 \\
\hline & & mutated SF3B1 & 1 & 2 \\
\hline & del(11q) and & $+8 \mathrm{q}$ & 1 & 2 \\
\hline & & $+8 q$ and del(17p) and mutated SF3B1 & 1 & 2 \\
\hline \multirow[t]{2}{*}{ Varia } & del(13q) and & RB1 loss & 8 & 19 \\
\hline & & biallelic loss of $13 q$ & 1 & 2 \\
\hline
\end{tabular}

del-deletion; tris-trisomy; dupl-duplication; N-number of patients

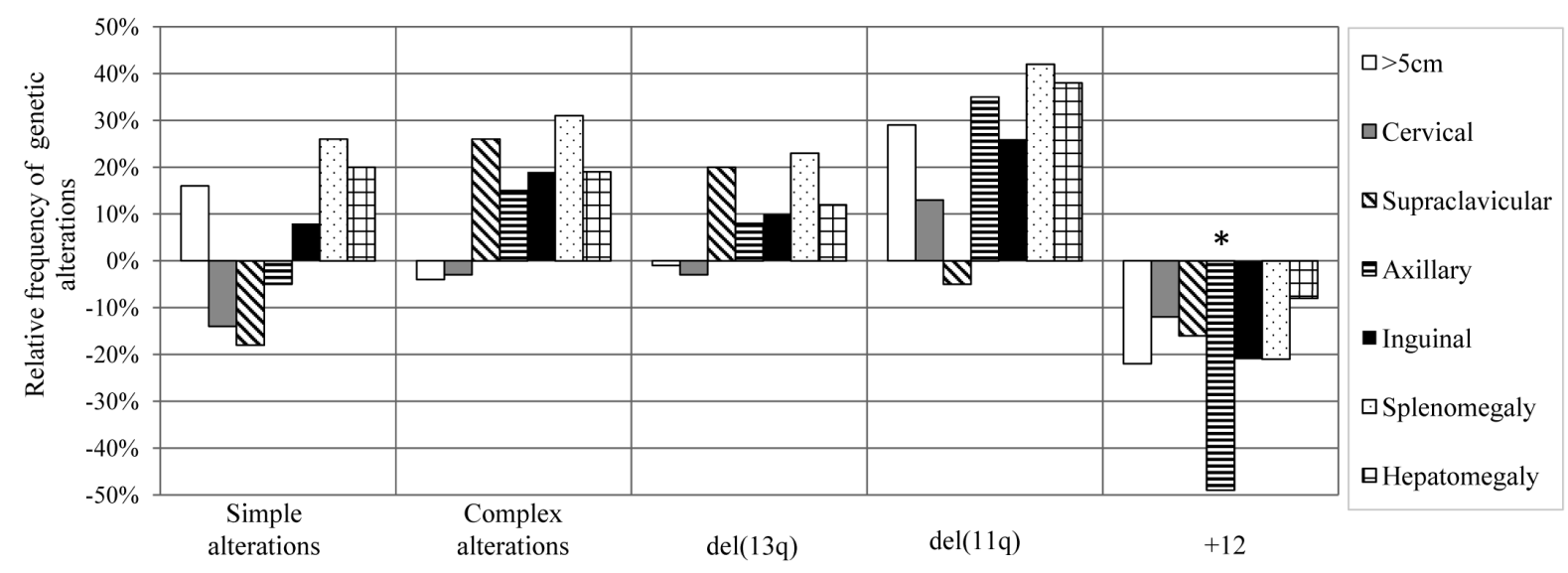

Figure 3. Relative frequency of genetic alterations in relation to the occurrence of clinical manifestations. The relative frequency was calculated by subtracting the percentages of patients presenting the genetic defect and clinical symptoms from those with the genetic defect and without clinical symptoms $* \mathrm{p}<0.05$ for the comparison between presence or absence of symptoms. 


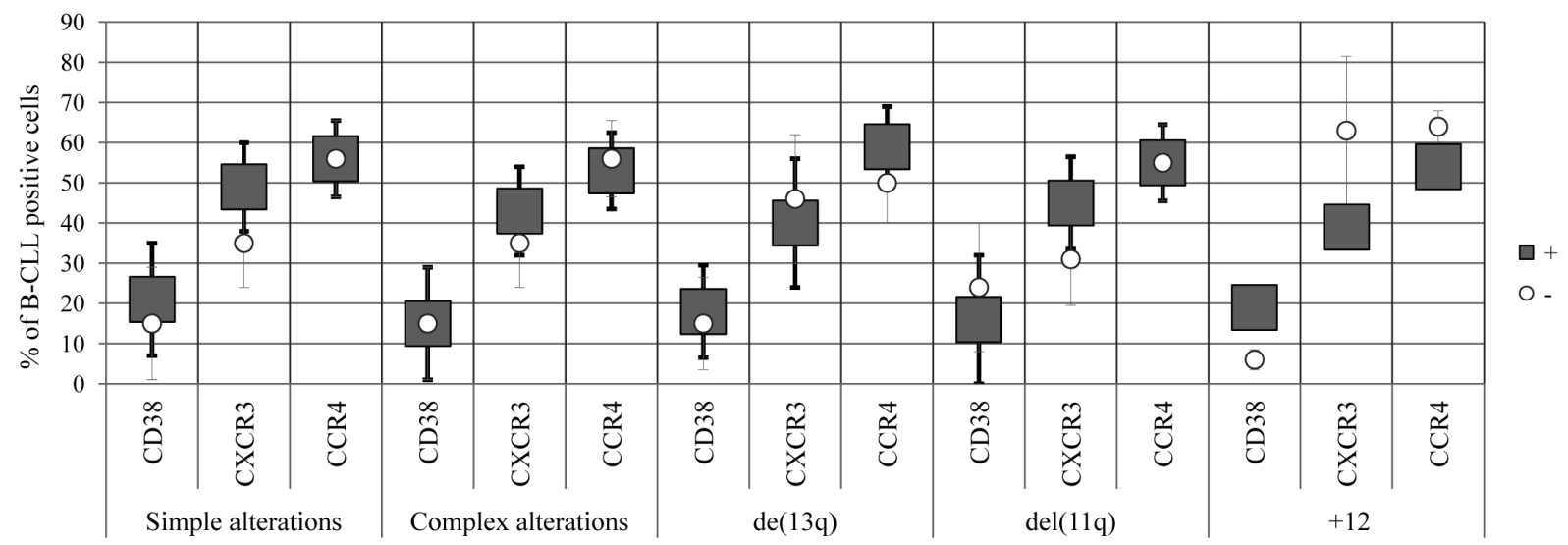

Figure 4. Frequency of CXCR3+, CCR4+ and CD38+ B-CLL cells in the PB of patients with or without cytogenetic alterations.

Mean values \pm standard deviation calculated for proportion of chemokine receptor and CD38 positivity in patients with (dark squares) or without (blank circles) genetic defect. PB-peripheral blood.

cells (cells/ $\mu \mathrm{L})$, including those with: cervical $(p=0.01)$, supraclavicular $(p=0.02)$, axillary $(\mathrm{p}=0.001)$, and inguinal $(\mathrm{p}=0.001)$ involvement.

When the CD4+ T-cells were classified according to the main maturation subsets, numbers of circulating EM cells (cells/ $\mu \mathrm{L}$ ) were found to be significantly higher in patients with cervical $(p=0.002)$, supraclavicular $(p=0.043)$, axillary $(p<0.001)$ and inguinal involvement $(p=0.003)$. Significantly higher numbers (cells/ $\mu \mathrm{L}$ ) of CM T-cells were found in patients with enlarged inguinal $(p=0.04)$ and axillary $(p=0.05) L N$. Higher regulatory $\mathrm{CD} 4+\mathrm{T}$ cell counts associated with cervical $(p=0.004)$ and axillary LN enlargement $(p=0.017)$, meanwhile TFH were only significantly increased in those patients with cervical $\mathrm{LN}(\mathrm{p}=0.02)$.

When the CD8+ T-cells were classified according to the main functional subsets, significantly higher counts of Tc1 and Tc3 cells (cells/ $\mu \mathrm{L}$ ) were found in patients with enlarged cervical (Tc1: $p=0.002$; Tc3: $p=0.006)$, supraclavicu$\operatorname{lar}(\mathrm{Tc} 1: \mathrm{p}=0.024 ; \mathrm{Tc} 3: \mathrm{p}=0.022)$, axillary $(\mathrm{Tc} 1$ : $\mathrm{p}<0.001 ; \mathrm{Tc} 3: \mathrm{p}=0.004)$, inguinal $(\mathrm{Tc} 1: \mathrm{p}<0.001$; Tc3: $\mathrm{p}<0.001)$, and $>5 \mathrm{~cm} \mathrm{LN} \mathrm{(Tc1:} \mathrm{p}=0.007$; Tc3: $p=0.02$ ). Also, the effector subset appears to be terminally differentiated (CD8+ CD57+ $\mathrm{T}$ cells) and seen mostly in patients presenting supraclavicular, inguinal and axillary enlarged lymph nodes (data not shown).

No statistically significant differences were observed between total circulating T-cells, total or subsets CD4+ T cells in B-CLL patients and organomegaly. In contrast, two T CD8+ subsets ( $\mathrm{Tc} 1$ and $\mathrm{Tc} 3$ ) were increased in absolute counts (cells/ $\mu \mathrm{L}$ ) in patients with splenomegaly (Tc1: $\mathrm{p}=0.01 ; \mathrm{Tc} 3: \mathrm{p}=0.02)$ and hepatomegaly $(\mathrm{Tc} 1$ : $\mathrm{p}=0.008 ; \mathrm{Tc} 3: \mathrm{p}=0.02)$.

\section{Chemokine receptors on $T$ cells in $B-C L L$ patients}

The association between CXCR3 and CCR4 expression in the CD4+ $\mathrm{T}$ cell subsets and the presence of LN was investigated. A significantly higher proportion of CXCR3+ cells was detected in the EM subset in patients with cervical $(50 \% \pm 21 \%$ vs $33 \% \pm 23 \%$; $\mathrm{p}=0.03)$, axillary $(56 \% \pm 20 \%$ vs $35 \% \pm 23 \%$; $p=0.005)$, and inguinal LN (57\% $\pm 20 \%$ vs $34 \% \pm 22 \%$; $p=0.003)$, but not in those with supraclavicular LN involvement. A higher CXCR3 expression on TFH in patients with inguinal $(57 \% \pm 23 \%$ vs $42 \% \pm 22 \%$; 

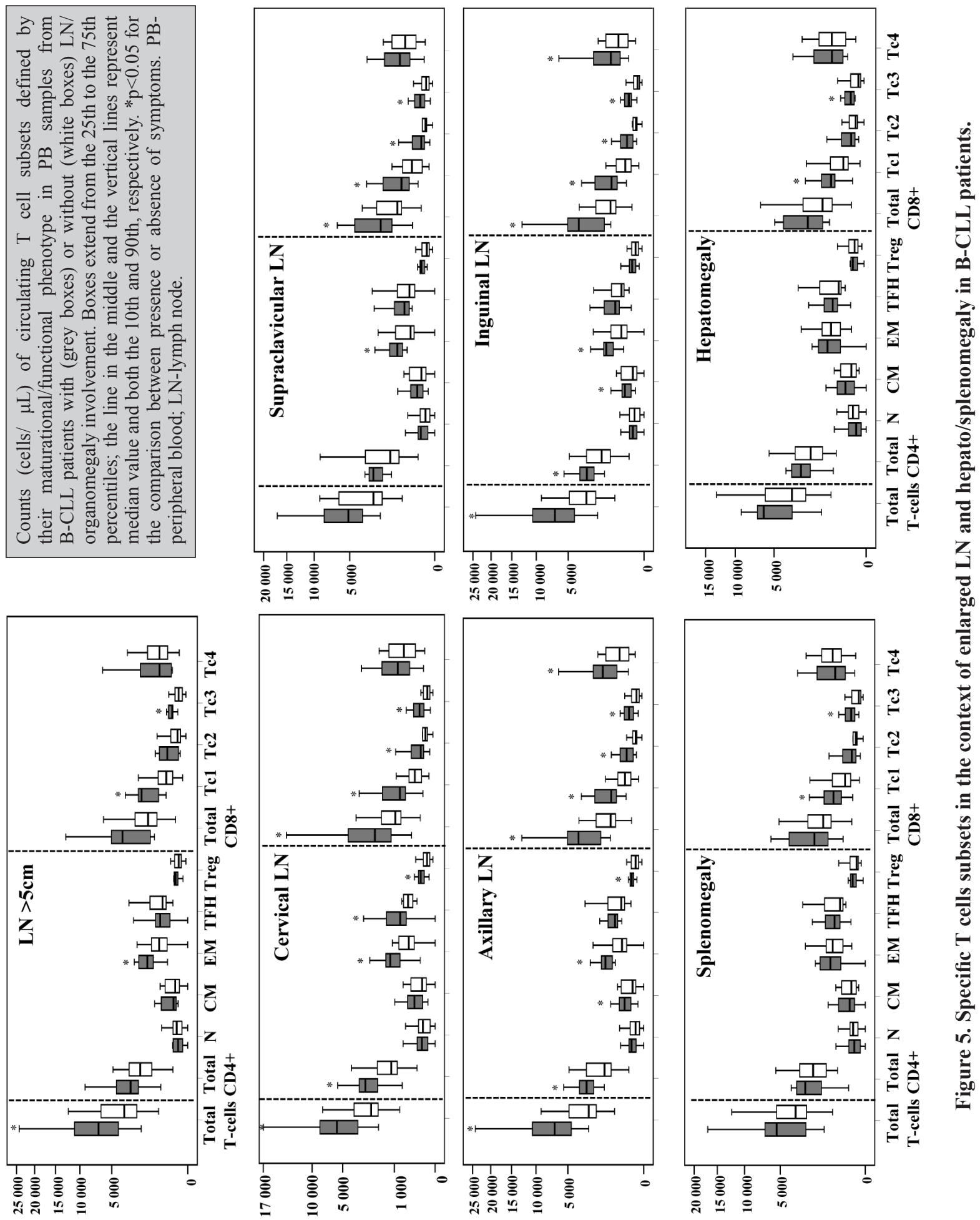
$\mathrm{p}=0.02)$ and supraclavicular $(57 \% \pm 17 \%$ vs $41 \% \pm 25 \%$; $p=0.04)$ was recorded. No significantly differences in CXCR3+ expression were detected for CM (data not shown). The frequency of CD4+ T-cell subsets expressing CCR4 was not significantly associated with the presence of adenopathies (data not shown).

\section{Discussions}

We documented here connection particularities between tumour microenvironment, genetic background, and tumour burden in a group of B-CLL patients.

Data from the literature point to chemokine receptors as crucial players in the development and progression of lymphoid neoplasms [6, 1019]. B- and T-cell circulation to $\mathrm{LN}$ has been proven to be strictly regulated by a combination of different chemokines (e.g. CXCR3, CXCR5, CCR7) $[20,21]$ and adhesion molecules such as CD38 [22] responsible not only for lymphocyte homing to, but also for the specific positioning within the follicles of LN, spleen and Peyer patches, inflammation sites, and linked with the process of extravasation through HEV-high endothelial venules [20, 21, 23, 24].

In our study the proportion of CCR4 positive B-CCL cells was found to be reduced in patients with particular clinical signs of LN/ organ involvement in comparison to those lacking such symptoms. While CCR4 has been previously reported to be over-expressed in some haematological malignancies [11-13] and solid tumors with a high metastatic potential [14-16], others, in line with our results, showed that, in B-CLL cells, CCR4 expression may be absent or significantly reduced when compared to normal B cells from elderly donors [25]. Hence, one may quickly infer that CCR4 does not qualify as a reliable diagnostic or therapeutic target for B-CLL patients. Nevertheless, such conclusion should be considered with caution, as high proportion of
CCR4 positive B-CLL cells and high intensity of their CCR4 expression have been documented to correlate with poor prognostic-associated factors (ZAP-70, CD38, Ki67) [25]. Besides, there are at least two other instances that may motivate the choice of using CCR4 blockage as a therapeutic alternative in B-CLL. One is the finding that CD40/CD40L - activated B-CLL secrete CCL17 and CCL22 which in turn stimulate the CCR4 expression on $\mathrm{T}$ cells that continue to provide proliferating signals for B cells [8]. The other is connected with the expression of CCR4 on regulatory $\mathrm{T}$ cells, therefore it may be used as a novel target for immunotherapy (depletion of Treg cells) in patients with different cancers [13].

The expression of CCR4 on T lymphocytes was also investigated in our study as a marker of Th2 helper phenotype (in contrast to CXCR3, associated with the Th1 phenotype) [26] but no significant association of CCR4 expression on any CD4+ T-cell subsets with the presence of adenopathies was established. Instead, a significantly higher proportion of CXCR3+ cells within the EM CD4+ T cell subset was found in the majority of patients with LN involvement and a CXCR3+ TFH subset significantly increased in circulation when adenopathies were present. If looking from the Th cytokine profile point of view, our results are in contradiction to data available in the literature suggesting a gradual change in composition of the T cell microenvironment from a Th1 to a Th2 phenotype with the evolution of the disease, in order to secure the selective advantage for tumor growth [27, 28]. Based on intracellular cytokines presence, a very recent study found a link between high proportions of circulating Th2 cells in B-CLL patients and the expression of the poor prognostic factor ZAP-70 [29]. If considering CXCR3 as a homing marker towards inflamed tissues, the noted expanded frequency of $\mathrm{T}$ cells expressing this chemokine receptor associated with LN involvement is not surprising. 
The expression of CXCR3 on the malignant clone was previously reported to be of prognostic value for B-CLL patients [28]. In our study CXCR3 proportion within the B-CLL pool was found to be lower (not significantly, though) in the occurrence of LN/ organ involvement. In line with our results, only patients with early stage B-CLL showed over-expression of CXCR3 [6, 17] and low CXCR3 expression was associated with advanced stage and poorer prognosis in B-CLL patients [6, 30]. Physiologically, CXCR3 is expressed in a small subset of normal circulating B lymphocytes (such as memory B cells, normal plasma cells, but not naive B cells), while in the vast majority of $\mathrm{LN}$ and splenic $\mathrm{B}$ cells it has been reported to be absent $[31,32]$. In lymphoproliferative disorders, others found CXCR3 expression on tumor cells in nearly all [31] or all [33] cases of B-CLL, but not in follicular or mantle lymphoma and high-grade lymphomas. The high variability of CXCR3 expression reported on normal/ malignant B-cells in various studies has been attributed to the instability of CXCR3 molecule during sample processing for flow cytometry detection [34] which may also explain the lack of statistical significance in our study, despite the obvious tendency. In solid tumors, a contrasting situation (over-expression associated with tumor growth and metastasis) have been documented [18, 19, 35, 36] while inhibitors of CXCR3 have been already tested efficient for their inhibitory role of metastases in colon cancer [35] and osteosarcoma [36].

Other two LN homing receptors, CCR7 and CXCR5, were find to be expressed on all B-CLL cells in our patient group, as previously described [20, 37]. Their expression apparently determines the nodal dissemination pattern and the erased LN architecture observed in patients with chronic lymphoproliferative disorders and LN involvement [37]. CCL19 and CCL21 secreted by HEV (high endothelial venules) and accessory cells are responsible for extravasation of CCR7+ cells (B, T or dendritic cells) and for directing the $\mathrm{B}$ cells towards $\mathrm{T}$ cell areas [38]. Interestingly, we found a direct correlation between CM T cells (identified by their memory phenotype and CCR7 positivity) and certain LN stations (inguinal and axillary), but not for spleen or liver enlargement, although it is clear that CD4+ T cells normally enter these organs, using probably other entering mechanisms. CXCR5 is also expressed by follicular $\mathrm{T}$ helper cells which we found increased especially in advanced Rai stages, in line with other studies [39].

A very recent study showed the connection between the expression of ZAP-70 in B-CLL patients, reduction of naïve $\mathrm{T}$ helper subsets, and the expansion of EM T cell subsets [29]. Although we found no differences and no associations between the circulating naive $T$ cells and the presence or absence of any secondary lymphoid organs involvement, an association between increased numbers of effector T cells and all LN chains enlargements was revealed. Whether this means that in the patients presenting certain LN chains the effector/central memory cells are produced in these locations, or whether these cells are not sequestered in these locations, it has to be investigated. We also found increased circulating numbers of $\mathrm{T}$ regs in advanced B-CLL and when cervical or axillary enlarged LN are present. Further studies need to be performed in order to define the meaning of the increased numbers of circulating $\mathrm{T}$ regs and the association with these specific lymphatic stations. There are studies suggesting that chemokines such as CCL3 and CCL4, secreted by the very B-CLL clone, are capable to recruit $\mathrm{T}$ regs, in order to ensure a proximate source of survival signals [40]. The precise role played by T regs in B-CLL is not fully elucidated, but recent studies prove that $\mathrm{CD} 4+\mathrm{T}$ regs have the capacity to inhibit policlonal B cells and effector T cells, downregulating the anti-tumoral response in B-CLL [41]. CD8+ T cells are found to be increased in our patient group whenever 
the clinical manifestations are present. In previous studies CD8 lymphocytosis correlates with disease progression and may also reflect a clonal expansion in B-CLL patients [42].

CD38 expression on B-CLL cells from our patient group was found to be increased regardless the LN chain involved and strongly related to $\mathrm{LN}$ larger than $5 \mathrm{~cm}$. The CD38 expression by B-CLL cells is considered of prognostic importance, a hallmark of a recent activation process $[43,44]$. In addition to its association with the B-CLL cell proliferative activity, it has been documented that leukemic cells from the bone marrow and the LN express higher amount of this molecule, suggesting that CD38 could be a molecular compass driving B-CLL cells to specialized niches [22].

Genetic lesions are common events in B-CLL, mostly in advanced stages of the disease and having unmutated IgVH. This may be explained by the polyreactivity of the BCR that determines an increased sensitivity to antigen contact, leading to an increased proliferation rate, which in turns raises the chance for the formation and accumulation of genetic aberrations [45]. The most frequent copy number variation in B-CLL, also found in our study, is the deletion of $13 \mathrm{q} 14$, either as single aberrancy, or in combination. Del(13q14) alone confers a good prognostic and is related to indolent disease, while in combination with other genetic lesions it is a marker of accumulated or acquired gene copy number variations lesions, for it is known that $\mathrm{miR} 15 / 16$ as part of the $13 \mathrm{q}$ deletion and that targets the $\mathrm{Bcl} 2$ expression, contributes to the pathogenesis of the disease [46]. We found no association between the presence of this DNA lesion, regardless the implication of RB1 gene (implicated in cell cycle control and chromosomal instability) [47] and none of the organ involvement studied in our group. Trisomy 12 is considered an intermediate prognostic factor in B-CLL patients. In our group, this genetic le- sion was more prevalent in patients presenting axillary LN involvement. Also it is well known that trisomy 12 along with NOTCH1 mutations identifies a group of patients with poor prognostic [48], but due to the size of our investigated group such analysis was not possible.

\section{Conclusions}

We demonstrated here that some specific functional $\mathrm{T}$ cell subsets associate with specific LN stations. Understanding the complicated interactions between the malignant cells and the surrounding factors is very important in finding the solutions for re- establishing the equilibrium. Further extended studies need to be performed in order to reveal the clinical application of such observations.

\section{Acknowledgments}

This research was financially supported by the European Social Fund within the project POSDRU/107/1.5/S/78702 „Inter-university partnership for increasing the medical doctoral research quality andinterdisciplinarity through doctoral scholarships Doc Med.net”.
Abbreviations
$\mathrm{B}-\mathrm{CLL}=\mathrm{B}$ - chronic lymphocytic leukemia
$\mathrm{LN}=$ lymph node
$\mathrm{CM}=$ central memory
$\mathrm{EM}=$ effector memory
$\mathrm{TFH}=$ follicullar $\mathrm{T}$ helper cells
$\mathrm{Tc}=$ cytotoxic $\mathrm{T}$ cells
$\mathrm{T}$ reg $=$ regulatory $\mathrm{T}$ cells
MLPA $=$ Multiplex Ligation-Dependent Probe
Amplification
$\mathrm{CD}=$ cluster of designation
$\mathrm{PB}=$ peripheral blood
$\min =$ minimum
$\max =$ maximum
$\operatorname{del}(13 q)=$ deletion of $13 q 14$ 
$\operatorname{del}(11 \mathrm{q})=$ deletion of $11 \mathrm{q}$

$+12=$ trisomy 12

$\operatorname{del}(17 \mathrm{p})=$ deletion of $17 \mathrm{p}$

\section{References}

1. Grigore GE, Dascalescu A, Zlei M, Ivanov IC, Danaila C, Petreus T, et al. Rai stage-related changes within T/ NK cell populations from B-CLL patients. Rev Romana Med Lab. 2013;21(3):321-31. DOI: $10.2478 / \mathrm{rrlm}-$ 2013-0032

2. D'Arena G, Guariglia R, La Rocca F, Trino S, Condelli V, De Martino L, et al. Autoimmune Cytopenias in Chronic Lymphocytic Leukemia. Clin Dev Immunol. 2013:730131. DOI: 10.1155/2013/730131

3. Hallek M. State-of-the-art treatment of chronic lymphocytic leukemia. ASH Education Program Book. 2009;2009(1):440-9.

4. Perez-Andres M, Paiva B, Nieto WG, Caraux A, Schmitz A, Almeida J et al. Human peripheral blood B-cell compartments: A crossroad in B-cell traffic. Cytometry Part B: Clinical Cytometry. 2010;78(S1):S47-S60. DOI: 10.1002/cyto.b.20547

5. Zenz T, Mertens D, Küppers R, Döhner H, Stilgenbauer S. From pathogenesis to treatment of chronic lymphocytic leukaemia. Nat Rev Cancer. 2010 Jan;10(1):3750. DOI: $10.1038 / \mathrm{nrc} 2764$

6. Davids MS, Burger JA. Cell trafficking in chronic lymphocytic leukemia. Open J Hematol. 2012;3(S1).

7. Caligaris-Cappio F. Role of the microenvironment in chronic lymphocytic leukaemia. British journal of haematology. 2003;123(3):380-8. DOI: 10.1046/j.13652141.2003.04679.x

8. Ghia P, Strola G, Granziero L, Geuna M, Guida G, Sallusto F, et al. Chronic lymphocytic leukemia B cells are endowed with the capacity to attract CD4+, CD40L $+\mathrm{T}$ cells by producing CCL22. European Journal of Immunology. 2002;32(5):1403-13. DOI: 10.1002/1521-4141(200205)32:5<1403::AID-IMMU1403>3.0.CO;2-Y

9. Fabris S, Scarciolla O, Morabito F, Cifarelli RA, Dininno $\mathrm{C}$, Cutrona $\mathrm{G}$, et al. Multiplex ligation-dependent probe amplification and fluorescence in situ hybridization to detect chromosomal abnormalities in Chronic lymphocytic leukemia: A comparative study. Genes, Chromosomes and Cancer. 2011;50(9):726-34. DOI: 10.1002/gcc.20894

10. Deutsch AJA, Steinbauer E, Hofmann NA, Strunk D, Gerlza T, Beham-Schmid C, et al. Chemokine receptors in gastric MALT lymphoma: loss of CXCR4 and upregulation of CXCR7 is associated with progression to diffuse large B-cell lymphoma. Mod Pathol. 2013 Feb;26(2):182-94.

11. Han T, Abdel-Motal UM, Chang D-K, Sui J, Muvaffak
A, Campbell J, et al. Human anti-CCR4 minibody gene transfer for the treatment of cutaneous t-cell lymphoma. PloS one. 2012;7(9):e44455. DOI: 10.1371/journal. pone. 0044455

12. Chang D-K, Sui J, Geng S, Muvaffak A, Bai M, Fuhlbrigge RC, et al. Humanization of an anti-CCR4 antibody that kills cutaneous T-cell lymphoma cells and abrogates suppression by T-regulatory cells. Molecular Cancer Therapeutics. 2012;11(11):2451-61. DOI: 10.1158/1535-7163.MCT-12-0278

13. Ishida $\mathrm{T}$, Ishii $\mathrm{T}$, Inagaki A, Yano H, Kusumoto S, Ri $\mathrm{M}$, et al. The CCR4 as a novel-specific molecular target for immunotherapy in Hodgkin lymphoma. Leukemia. 2006;20(12):2162-8. DOI: 10.1038/sj.leu.2404415

14. Al-haidari Amr A., Syk I, Jirström K, Thorlacius H. CCR4 mediates CCL17 (TARC)-induced migration of human colon cancer cells via RhoA/Rho-kinase signaling. Int J Colorectal Dis. 2013 Nov 1;28(11):1479-87. DOI: 10.1007/s00384-013-1712-y

15. Li J-Y, Ou Z-L, Yu S-J, Gu X-L, Yang C, Chen A-X et al. The chemokine receptor CCR4 promotes tumor growth and lung metastasis in breast cancer. Breast cancer research and treatment. 2012;131(3):837-48. DOI: 10.1007/s10549-011-1502-6

16. Tsujikawa T, Yaguchi T, Ohmura G, Ohta S, Kobayashi A, Kawamura N, et al. Autocrine and paracrine loops between cancer cells and macrophages promote lymph node metastasis via CCR4/CCL22 in head and neck squamous cell carcinoma. Int J Cancer. 2013 Jun 15;132(12):2755-66. DOI: 10.1002/ijc.27966

17. Mahadevan D, Choi J, Cooke L, Simons B, Riley C, Klinkhammer T, et al. Gene Expression and Serum Cytokine Profiling of Low Stage CLL Identify WNT/ PCP, Flt-3L/Flt-3 and CXCL9/CXCR3 as Regulators of Cell Proliferation, Survival and Migration. Hum Genomics Proteomics. 2009;2009:453634. DOI: $10.4061 / 2009 / 453634$

18. Singh AK, Arya RK, Trivedi AK, Sanyal S, Baral $\mathrm{R}$, Dormond $\mathrm{O}$, et al. Chemokine receptor trio: CXCR3, CXCR4 and CXCR7 crosstalk via CXCL11 and CXCL12. Cytokine Growth Factor Rev. 2013 Feb;24(1):41-9. DOI: 10.1016/j.cytogfr.2012.08.007

19. Mulligan AM, Raitman I, Feeley L, Pinnaduwage D, Nguyen LT, O'Malley FP, et al. Tumoral Lymphocytic Infiltration and Expression of the Chemokine CXCL10 in Breast Cancers from the Ontario Familial Breast Cancer Registry. Clinical Cancer Research. 2013;19(2):336-46. DOI: 10.1158/1078-0432.CCR-113314

20. Bürkle A, Niedermeier M, Schmitt-Gräff A, Wierda WG, Keating MJ, Burger JA. Overexpression of the CXCR5 chemokine receptor, and its ligand, CXCL13 in B-cell chronic lymphocytic leukemia. Blood. 2007;110(9):3316-25. DOI: 10.1182/ blood-2007-05-089409 
21. Okada T, Ngo VN, Ekland EH, Förster R, Lipp M, Littman DR, et al. Chemokine requirements for B cell entry to lymph nodes and Peyer's patches. The Journal of experimental medicine. 2002;196(1):65-75. DOI: 10.1084/jem.20020201

22. Malavasi F, Deaglio S, Damle R, Cutrona G, Ferrarini M, Chiorazzi N. CD38 and chronic lymphocytic leukemia: a decade later. Blood. 2011;118(13):3470-8. DOI: 10.1182/blood-2011-06-275610

23. Nagira M, Imai $T$, Yoshida R, Takagi S, Iwasaki M, Baba M, et al. A lymphocyte-specific CC chemokine, secondary lymphoid tissue chemokine (SLC), is a highly efficient chemoattractant for $\mathrm{B}$ cells and activated $\mathrm{T}$ cells. European Journal of Immunology. 1998;28(5):1516-23. DOI: 10.1002/ (SICI) 1521-4141(199805)28:05<1516::AID-IMMU1516>3.0.CO;2-J

24. Kunkel EJ, Butcher EC. Plasma-cell homing. Nature Reviews Immunology. 2003;3(10):822-9. DOI: 10.1038/nri1203

25. Nannini PR, Borge M, Mikolaitis VC, Abreu C, Morande $\mathrm{PE}$, Zanetti SR, et al. CCR4 expression in a case of cutaneous Richter's transformation of chronic lymphocytic leukemia (CLL) to diffuse large B-cell lymphoma (DLBCL) and in CLL patients with no skin manifestations. European Journal of Haematology. 2011;87(1):80-6. DOI: 10.1111/j.16000609.2011.01613.x

26. Kim CH, Rott L, Kunkel EJ, Genovese MC, Andrew $\mathrm{DP}, \mathrm{Wu} \mathrm{L}$, et al. Rules of chemokine receptor association with $\mathrm{T}$ cell polarization in vivo. Journal of Clinical Investigation. 2001;108(9):1331-9. DOI: 10.1172/ JCI200113543

27. Cózar JM, Canton J, Tallada M, Concha A, Cabrera T, Garrido F, et al. Analysis of NK cells and chemokine receptors in tumor infiltrating CD4 $\mathrm{T}$ lymphocytes in human renal carcinomas. Cancer Immunology, Immunotherapy. 2005;54(9):858-66. DOI: $10.1007 /$ s00262004-0646-1

28. Svensson H, Olofsson V, Lundin S, Yakkala C, Björck $\mathrm{S}$, Börjesson L, et al. Accumulation of CCR4+ CTLA-4hi FOXP3+ CD25hi regulatory $\mathrm{T}$ cells in colon adenocarcinomas correlate to reduced activation of conventional T cells. PloS one. 2012;7(2):e30695. DOI: 10.1371/journal.pone.0030695

29. Monserrat J, Ángel Sánchez M, de Paz R, Díaz D, Mur $\mathrm{S}$, Reyes E, et al. Distinctive patterns of naïve/memory subset distribution and cytokine expression in CD4 T lymphocytes in ZAP-70 B-chronic lymphocytic patients. Cytometry Part B: Clinical Cytometry. 2013. DOI: $10.1002 /$ cytob. 21120

30. Ocana E, Delgado-Perez L, Campos-Caro A, Munoz J, Paz A, Franco R, et al. The prognostic role of CXCR3 expression by chronic lymphocytic leukemia B cells.
Haematologica. 2007;92(3):349-56. DOI: 10.3324/haematol.10649

31. Jones D, Benjamin RJ, Shahsafaei A, Dorfman DM. The chemokine receptor CXCR3 is expressed in a subset of B-cell lymphomas and is a marker of B-cell chronic lymphocytic leukemia. Blood. 2000;95(2):62732.

32. Giuliani N, Bonomini S, Romagnani P, Lazzaretti M, Morandi F, Colla S, et al. CXCR3 and its binding chemokines in myeloma cells: expression of isoforms and potential relationships with myeloma cell proliferation and survival. Haematologica. 2006;91(11):148997.

33. Trentin L, Agostini C, Facco M, Piazza F, Perin A, Siviero $\mathrm{M}$, et al. The chemokine receptor CXCR3 is expressed on malignant $\mathrm{B}$ cells and mediates chemotaxis. Journal of Clinical Investigation. 1999;104(1):115-21. DOI: $10.1172 /$ JCI7335

34. Wong S, Fulcher D. Chemokine receptor expression in B-cell lymphoproliferative disorders. Leukemia \& lymphoma. 2004;45(12):2491-6. DOI: 10.1080/10428190410001723449

35. Cambien B, Karimdjee B, Richard-Fiardo P, Bziouech H, Barthel R, Millet M, et al. Organ-specific inhibition of metastatic colon carcinoma by CXCR3 antagonism. British journal of cancer. 2009;100(11):1755-64. DOI: 10.1038/sj.bjc. 6605078

36. Pradelli E, Karimdjee-Soilihi B, Michiels JF, Ricci JE, Millet MA, Vandenbos F, et al. Antagonism of chemokine receptor CXCR3 inhibits osteosarcoma metastasis to lungs. International Journal of Cancer. 2009;125(11):2586-94. DOI: 10.1002/ijc. 24665

37. López-Giral S, Quintana NE, Cabrerizo M, Alfonso-Pérez M, Sala-Valdés M, de Soria VGG, et al. Chemokine receptors that mediate $\mathrm{B}$ cell homing to secondary lymphoid tissues are highly expressed in B cell chronic lymphocytic leukemia and non-Hodgkin lymphomas with widespread nodular dissemination. Journal of leukocyte biology. 2004;76(2):462-71. DOI: 10.1189/jlb.1203652

38. Reif K, Ekland EH, Ohl L, Nakano H, Lipp M, Förster $\mathrm{R}$, et al. Balanced responsiveness to chemoattractants from adjacent zones determines B-cell position. Nature. 2002;416(6876):94-9. DOI: 10.1038/416094a

39. Cha Z, Zang Y, Guo H, Rechlic JR, Olasnova LM, Gu $\mathrm{H}$, et al. Association of peripheral CD4+ CXCR5+ T cells with chronic lymphocytic leukemia. Tumour Biol. 2013 Dec;34(6):3579-85. DOI: 10.1007/s13277-0130937-2

40. Bystry RS, Aluvihare V, Welch KA, Kallikourdis M, Betz AG. B cells and professional APCs recruit regulatory $\mathrm{T}$ cells via CCL4. Nature immunology. 2001;2(12):1126-32. DOI: 10.1038/ni735

41. Jadidi-Niaragh F, Yousefi M, Memarian A, Hojjat-Farsangi M, Khoshnoodi J, Razavi SM, et al. Increased 
Frequency of CD8+ and CD4+ Regulatory T Cells in Chronic Lymphocytic Leukemia: Association with Disease Progression. Cancer investigation. 2013;31(2):12131. DOI: 10.3109/07357907.2012.756110

42. Scrivener S, Goddard R, Kaminski E, Prentice A. Abnormal T-cell function in B-cell chronic lymphocytic leukaemia. Leukemia \& lymphoma. 2003;44(3):383-9. DOI: $10.1080 / 1042819021000029993$

43. Damle RN, Temburni S, Calissano C, Yancopoulos S, Banapour T, Sison C, et al. CD38 expression labels an activated subset within chronic lymphocytic leukemia clones enriched in proliferating B cells. Blood. 2007;110(9):3352-9. DOI: 10.1182/ blood-2007-04-083832

44. Zucchetto A, Benedetti D, Tripodo C, Bomben R, Dal Bo M, Marconi D, et al. CD38/CD31, the CCL3 and CCL4 chemokines, and CD49d/vascular cell adhesion molecule-1 are interchained by sequential events sustaining chronic lymphocytic leukemia cell survival. Cancer research. 2009;69(9):4001-9. DOI: 10.1158/0008-5472.CAN-08-4173

45. Herishanu Y, Pérez-Galán P, Liu D, Biancotto A, Pit- taluga S, Vire B, et al. The lymph node microenvironment promotes B-cell receptor signaling, NF- $\kappa \mathrm{B}$ activation, and tumor proliferation in chronic lymphocytic leukemia. Blood. 2011;117(2):563-74. DOI: 10.1182/ blood-2010-05-284984

46. Palamarchuk A, Efanov A, Nazaryan N, Santanam U, Alder $H$, Rassenti L, et al. 13q14 deletions in CLL involve cooperating tumor suppressors. Blood. 2010;115(19):3916-22. DOI: 10.1182/ blood-2009-10-249367

47. Ouillette P, Collins R, Shakhan S, Li J, Li C, Shedden $\mathrm{K}$, et al. The prognostic significance of various 13 q14 deletions in chronic lymphocytic leukemia. Clinical Cancer Research. 2011;17(21):6778-90. DOI: 10.1158/1078-0432.CCR-11-0785

48. Del Giudice I, Rossi D, Chiaretti S, Marinelli M, Tavolaro S, Gabrielli S, et al. NOTCH1 mutations in +12 chronic lymphocytic leukemia (CLL) confer an unfavorable prognosis, induce a distinctive transcriptional profiling and refine the intermediate prognosis of + 12 CLL. Haematologica. 2012;97(3):437-41. DOI: 10.3324/haematol.2011.060129 